\title{
Evaluation on physiological biomarkers pre and during gestational period in immunosuppressed Wistar rats with mycophenolate sodium
}

\author{
Amanda Lima Deluque*, Nagilla Orleanne Lima do Carmo, Elisangela Miranda de Jesus Lisboa, \\ Gilsielle Benício Jaco, Betina Beatriz Mielke, Madileine Francely Americo, Luciana Aparecida Cora, \\ Maria do Carmo Borges Teixeira, Kleber Eduardo de Campos
}

From 20th Brazilian Diabetes Society Congress

Porto Alegre, Brazil. 11-18 November 2015

\section{Background}

The use of medication during pregnancy should be taken with caution, especially because of its implications for maternal and fetal health. The mycophenolate sodium (MFS) is used to avoid possible rejection of transplanted tissues and organs by inhibiting $\mathrm{T}$ and $\mathrm{B}$ lymphocyte proliferation.

\section{Objective}

To evaluate the effects of maternal immunosuppression by MFS on physiological parameters in rats.

\section{Materials and methods}

The rats were divided into three groups: rats treated with water $(C O N T=10)$ rats orally treated with MFS $(20 \mathrm{mg} /$ $\mathrm{Kg}$ ) daily for 15 days until a positive diagnosis of pregnancy $(\mathrm{MICO}-1=10)$ and rats orally treated with MFS $(20 \mathrm{mg} / \mathrm{Kg})$ daily for 15 days prior to and during 21 days of pregnancy $(\mathrm{MICO}-2=10)$. It was weekly evaluated body weight, blood glucose, and water and food intake (before and during pregnancy). Statistical significance was $\mathrm{p}<0.05$.

\section{Results}

In the pre-pregnancy period, although there were no changes in body weight values, the continuous treatment with MFS decreased food and water consumption and also increased blood glucose (MICO-2). During pregnancy period, these rats presented a reduction of the

\footnotetext{
* Correspondence: amandalima_00@hotmail.com

Universidade Federal de Mato Grosso, Barra do Garças, Brazil
}

body weight, maintaining a mild hyperglycemia level (about $170 \mathrm{mg} / \mathrm{dL}$ )

\section{Conclusion}

The continued use of MFS during pregnancy can be considered toxic, damaging the maternal health, lead to mild hyperglycemia state plus some toxic data (low food and water intake). This study shows that MFS use is not recommended during pregnancy freely and should be replaced by another immunosuppressant.

Published: 11 November 2015

doi:10.1186/1758-5996-7-S1-A69

Cite this article as: Deluque et al:: Evaluation on physiological biomarkers pre and during gestational period in immunosuppressed Wistar rats with mycophenolate sodium. Diabetology \& Metabolic Syndrome 2015 7(Suppl 1):A69.

Submit your next manuscript to BioMed Central and take full advantage of:

- Convenient online submission

- Thorough peer review

- No space constraints or color figure charges

- Immediate publication on acceptance

- Inclusion in PubMed, CAS, Scopus and Google Scholar

- Research which is freely available for redistribution

Submit your manuscript at www.biomedcentral.com/submit 